\title{
Towards Adaptive E-Learning among University Students: by Applying Technology Acceptance Model (TAM)
}

\author{
Mahdi M Alamri, Waleed Mugahed Al-Rahmi, Noraffandy Yahaya, Ali Mugahed Al-Rahmi, \\ Hussein Abualrejal, Akram M. Zeki, Qusay Al-Maatouk
}

\begin{abstract}
E-learning is a form of education that is increasingly being used in higher education in the developed world. The aim of the study was to evaluating students' satisfaction of e-Learning. In this research, we apply and use the theory of technology acceptance model (TAM). We employ structural equation modelling (SEM) approach with SmartPLS software to investigate students' adoption process. Findings indicates that the perceived ease of use, perceived usefulness and intention to use e-learning among university students have a positive impact and substantially associated with learning performance and learning satisfaction. The study concludes that university students in Malaysia have positive perceptions towards e-learning and intend to practice it for educational purposes.
\end{abstract}

Index Terms: Structural Equation Modeling (SEM), E-Learning, University students', TAM.

\section{INTRODUCTION}

Any online learning that is based on technical training and tuition is known as E-learning [1]. Being provided with this type of learning, learners are able to take part and experience many activities through having a virtual environment. Such activities can vary from investigations to audiovisual interactions in relation to different subjects. Furthermore, both students and teachers can communicate interactively through e-learning. Educational institutions are strongly recommended to support the use of these e-learning virtual courses to identify the major changes in such e-learning

Revised Manuscript Received on September 22, 2019.

Mahdi M Alamri*, College of Education, Education Technology Department, King Faisal University, Alahsa 31982, Saudi Arabia

Waleed Mugahed Al-Rahmi, Faculty of Social Sciences \& Humanities, School of Education, Universiti Teknologi Malaysia, 81310, UTM Skudai, Johor, Malaysia

Noraffandy Yahaya, Faculty of Social Sciences \& Humanities, School of Education, Universiti Teknologi Malaysia, 81310, UTM Skudai, Johor, Malaysia

Ali Mugahed Al-Rahmi, Faculty of Technology Management and Business, Universiti Tun Hussein Onn Malaysia, Batu Pahat, Johor, Malaysia

Hussein Abualrejal, School of Technology Management \& Logistic, University Utara Malaysia, 06010 UUM Sintok, Kedah Darul Aman, Malaysia

Akram M. Zeki, Faculty of Information and Communication Technology, International Islamic University Malaysia, P.O Box 10, 50728, Kuala Lumpur, Malaysia

Qusay Al-Maatouk, Faculty of Engineering, Computing and Technology, Asia Pacific University of Technology \& Innovation (APU), Technology Park Malaysia, Bukit Jalil-57000 Kuala Lumpur, Malaysia

*Corresponding Author Email: mahdi@kfu.edu.sa practices. Many international universities around the world have adopted these e- learning tools. This term "e-learning" refers to any learning process that makes use of internet for the purpose of interaction [2]. This definition was given a more inclusive nature by [3] who re-defined this term to involve delivering, enabling or mediating anything through electronic technology for the purpose of learning [4]. In a more detailed definition, [5] claimed that the letter "e" in e-learning stands for "evolving, enhanced, everywhere, every time and everybody" rather than referring only to electronic. This detailed view highlights the benefits this type of learning provides for both learners and instructors. This term of e-learning is not new and it was approached by many researchers. However, investigating the area of students' motivation in the use of e-learning has received little attention. $[6,7]$ refer to e-learning as the use of multimedia technologies and internet for the purpose of improving and enhancing the use of services and resources. This also includes the remote exchange and collaboration. Looking at the different previous theoretical models, it is observed that a number of these models investigated the individuals' satisfaction through the use of e-learning but not enough models addressing or evaluating usefulness. Looking at this area of research in Malaysia, it is observed that there is a need to develop models in order to understand the use of e-learning and its influence of learning performance in higher educational institutions $[6,7,10]$. Investigating the challenges faced by educational institutions, $[11,12]$ reported that seven universities forming $26.9 \%$ did not have an e-learning unit or center. Another challenge reported, as observed in data obtained from three institutions forming $11.5 \%$, was that this type of learning was did not receive enough encouragement and support from the management. Even though e-learning has been adopted by a considerable number of universities worldwide, there is a need to look at the intention of using e-learning $[7,10]$.

\section{The ReSEarch MOdeI}

Through the use of decision support systems, the current study looks at variables perceived ease of use and perceived usefulness towards adaptive e-learning being two important tested tam variables. This study is expected to give more insights on the use of e-learning through exploring the relation between Decision support satisfaction and there two variables. It has been proven through research that TAM models are efficient in predicting usage behavior and user acceptance. The influence of 
system characteristics as antecedents to ease of use or perceived usefulness have received little attention by TAM studies [13]. Taking into consideration the investigation the system and information characteristics, their influence on the core beliefs in TAM and their indirect role of shaping system from Davis's original model, adding little casual explanatory power, the attitude towards using construct was dropped in the revised TAM. Due to the fact that the revised TAM does not consider external variables, the construct relevant to External Variables was dropped. According to Davis et al [15], setting the stage for examining the influence of external variables on internal beliefs, attitudes, intentions, and usage is considered a prime aim of TAM. When comparing between TAM and research grounded in Innovation Diffusion Theory Rogers, it is found that the prediction of adoption requires a complex set of beliefs [16]. In TAM, the Rogers's relative advantage corresponds to Perceived usefulness while complexity can be an equivalent to the ease of use. The by Perceived innovation attributes. This study aims as simplifying the model (See Figure 1) proposed for the purpose of examining both learning performance and learning satisfaction within Malaysian higher educational institutions through intention to use e-learning. To do this, the current study is using the TAM Model. This study found out a significant relation between perceived usefulness (PU) and perceived ease of use (PEU) on one side and the intention to use e-learning (IU) to enhance learning performance (LP) and learning satisfaction (LS) from the other side. Based on the above-discussed, a number of hypotheses are proposed in the current study.

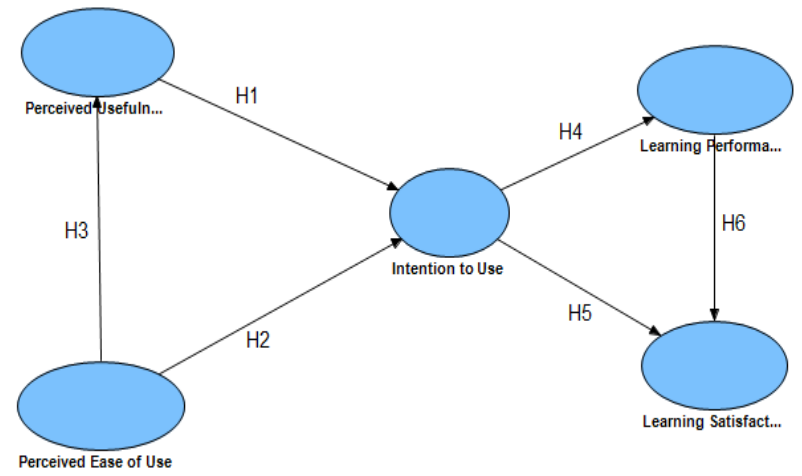

Figure 1: Research Model

\section{A. Perceived Usefulness and Perceived Ease of Use}

According to TAM, it is presumed that conscious decision making processes are responsible for forming the behavioural intention [14]. This model further highlights perceived usefulness (PU), perceived ease of use (PEOU), Perceived usefulness (PU) being three major salient factors relevant to information technology usage and acceptance. PU refers to extent people believe that their performance can be enhanced through the use of a certain system while the level to which they believe that use of a certain system would be effortless is known as Perceived ease of use (PEOU) [15]. These two terms are examples of cognitive factors. In the context of TAM, the evaluative effect of positive or negative feeling of individuals in performing a particular behavior is known as the attitude towards usage [16]. The users' feeling weather the use of a particular system would be mentally effortless or not usage was highlighted by Venkatesh et al. [14]. Different amount of innovation acceptance or usage can be explained

is known as the perceived ease of use [15]. The relation between innovation characteristics and their adoption was examined by Tornatzky and Klein [17]. They found that the level of innovation acceptance can be determined by three factors headed by complexity of innovation. Furthermore, Systems that are easy to use are more likely chosen by users rather than the useful ones. The performance benefits of a certain system, such as e-learning, can be less than its difficulties when it is difficult to use it. The ease of operating level; rigidness and flexibility of system; and the effort needed to learn and use the system are factors that can be used to measure the perceived ease of use [18].

\section{B. Intention to Use}

The intention to perform a precise behavior or a certain action is known as the BIU [19]. This terms becomes useful when looking at Corresponding behavior prediction which indicates the readiness of users to do voluntary actions. Therefore, seemingly the intention to capture the motivating factors that affect behavior; those factors are indicators of how stubborn people are ready to try, how much effort they are planning to exercise, in order to involve in a behavior, the power of intention is decided by the subjective probability that an individual will perform the action [15]. The users' willingness of using new information technology is known as the intention of using a new information technology [20]. Research found out that PU and PEU have a strong influence on intention TAM. Staff attitudes toward the use of a certain system are also found to be determined by these factors. The use intention can be predicted by PU leading to the actual system use. behavioral intentions can be directly and indirectly affected by PEU and PU [14, 15]. In other studies, the intention was claimed to be directly affected by PU and indirectly affected by PEU through PU. Similarly, Chen et al. [21] reported that intention is directly influenced by PU being the only factor with a direct effect. Having another opinion, [22] claimed that the influence of usefulness on use intention is a situation-dependent taking into consideration that the beliefs about use intentions are mainly predicted by PU and PEU. Generally, the use of a technology is found to be mainly influenced by the ease and the usefulness of use. Based on these points, the current study proposed a number of hypotheses. It was found, in the Malaysian context, that deciding to adopt and continue to use a particular technology is mainly determined by PEU and PU

\section{Learning Performance}

In relation to student success and the use of online, studies have uncovered that student engagement and their academic outcomes are positively influenced by the different online learning tools [21]. In details, this success was represented by the students' ability to use higher order thinking, reflective learning, and integrative learning in their study. These skills helped the students to achieve better outcomes such as general education; practical competence; and personal and social development" (p.1230). Chen et al added that getting high scored is also one of the advantages of adopting online learning. lecture attendance was found to be negatively affected by online learning as students' can access the materials online such as PowerPoint slides [24].

\section{Published By:}




\section{Learning Satisfaction}

In the context of tertiary education, this area has been approached by much research. Some researchers explore and investigated communication and the concept of e-learning development in terms of strategies [26]. Other researchers were interested in the impact of e-learning in UTM. Some studies aimed at studying the Model of Technology Acceptance (TAM) of e-learning in UTM [27]. However, little attention was given to the issue of students 'satisfactions Therefore, this study is an attempts to develop a model of evaluation to examine learners' satisfaction with e-learning ins UTM.

\section{RESEARCH MYTHOLOGY}

The main tool of data collected used in this study was a survey questionnaire. A total of 226 students received this survey in the year 2017/2018. This survey required students to talk about their experiences in using e-learning. The hypotheses in this study are tested using a quantitative approach (positivism paradigm). 106 of the participants were males and the rest were females. In particular, students were asked to fill in the questionnaire about their experiences using e-learning and its influence on their learning performance and satisfaction. The participant of this research were UTM students.

\section{A. Respondents}

The questionnaires were randomly distributed among 226 University Teknologi Malaysia students (UTM) students. IBM SPSS Version 21 and Partial Least Squares Structural Equation Modeling (PLS-SEM) in Smart PLS package 3.0. were the major tools of analysis. Based on the study aims and objectives, the different factors of this study were developed: The instrument was also tested for its reliability and the result was positive as Cronbach's alpha 0.935 . The questions in the questionnaire were made easy for students to understand and they were also divided into five categories for organizational purposes.

\section{B. Data Collection Procedures}

Five-point Likert scale was adopted: 1 depicting strongly disagree and 5 depicting strongly agree. Before conducting the actual study, the researcher conducted a pilot study for: two purposes. First, to make sure that the questions are easy to understand by the students. Second, to solicit the students, feedback on their use of e-learning and how this affects their academic performance and satisfaction. This examination was done through the use of TAM theory in the context of Malaysian higher educational institution. The survey comprised of 28 questions. All of the participants were briefed about the nature of the study prior to filling up the questionnaire. These 28 items were adopted and adapted from different sources and they were used to measure different constructs. In particular, eighteen questions were adopted form Davis [15] and were chosen to measure perceived ease of use, intention to use e-learning and perceived usefulness. Another five items were adopted from [10, 28] and they were used in this study to assess learning performance. Other items were adopted from $[6,7,28]$ and were used to assess learning satisfaction. The constructs of the survey were perceived usefulness (PU), perceived ease of use (PE), intention to use e-learning (IU), learning performance (LP) and learning satisfaction (LS). Table 1 illustrated the items used in the current study and the resources they were adapted from. The acronyms below are used to refer to the following constructs;

Table 1: Construct measurement

\begin{tabular}{|c|c|c|c|c|}
\hline Items & Measure & $\mathbf{F}$ & Items & Measure \\
\hline $\begin{array}{c}\text { PEU } \\
1\end{array}$ & $\begin{array}{l}\text { I found e-learning easy to } \\
\text { use }\end{array}$ & \multirow{6}{*}{ 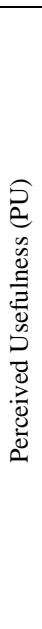 } & PU 1 & $\begin{array}{l}\text { Using e-learning would } \\
\text { enhance my } \\
\text { effectiveness in } \\
\text { learning }\end{array}$ \\
\hline $\begin{array}{c}\text { PEU } \\
2\end{array}$ & $\begin{array}{l}\text { Learning to use } \\
\text { e-learning would be easy } \\
\text { for me }\end{array}$ & & PU 2 & $\begin{array}{l}\text { Using e-learning would } \\
\text { improve my course } \\
\text { performance. }\end{array}$ \\
\hline $\begin{array}{l}\text { PEU } \\
3\end{array}$ & $\begin{array}{l}\text { My interaction with } \\
\text { e-learning was clear and } \\
\text { understandable }\end{array}$ & & PU 3 & $\begin{array}{l}\text { Using e-learning would } \\
\text { increase my } \\
\text { productivity in my } \\
\text { course work. }\end{array}$ \\
\hline $\begin{array}{c}\text { PEU } \\
4\end{array}$ & $\begin{array}{l}\text { It would be easy for me } \\
\text { to find information at } \\
\text { e-learning }\end{array}$ & & PU 4 & $\begin{array}{l}\text { I found e-learning } \\
\text { useful. }\end{array}$ \\
\hline $\begin{array}{c}\text { PEU } \\
5\end{array}$ & $\begin{array}{l}\text { Using e-learning is easy } \\
\text { to understand. }\end{array}$ & & PU 5 & $\begin{array}{l}\text { Using e- learning } \\
\text { improves the quality of } \\
\text { our work. }\end{array}$ \\
\hline $\begin{array}{l}\text { PEU } \\
6\end{array}$ & $\begin{array}{l}\text { Using e- learning does } \\
\text { not require a lot of effort. }\end{array}$ & & PU 6 & $\begin{array}{l}\text { Using e- learning } \\
\text { supports critical aspects } \\
\text { of our work. }\end{array}$ \\
\hline LP 1 & $\begin{array}{l}\text { I agree that using the } \\
\text { e-learning system can } \\
\text { effectively help me to } \\
\text { understand } \\
\text { mathematical concepts. }\end{array}$ & \multirow{6}{*}{ 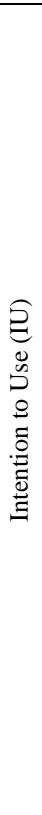 } & IU 1 & $\begin{array}{l}\text { I intend to use } \\
\text { e-learning during the } \\
\text { semester. }\end{array}$ \\
\hline LP 2 & $\begin{array}{l}\text { I feel that e-learning } \\
\text { system promotes my } \\
\text { learning confidence. }\end{array}$ & & IU 2 & $\begin{array}{l}\text { I will return to } \\
\text { e-learning often. }\end{array}$ \\
\hline LP 3 & $\begin{array}{l}\text { I agree that my } \\
\text { mathematical score has } \\
\text { progressed due to using } \\
\text { e-learning system. }\end{array}$ & & IU 3 & $\begin{array}{l}\text { I intent to visit } \\
\text { e-learning frequently for } \\
\text { my course work. }\end{array}$ \\
\hline LP 4 & $\begin{array}{l}\text { Using e-learning to } \\
\text { facilitate academic } \\
\text { activities and coordinate } \\
\text { with my peers and } \\
\text { lecturers. }\end{array}$ & & IU 4 & $\begin{array}{l}\text { I think that using e- } \\
\text { learning is a good idea. }\end{array}$ \\
\hline \multirow[t]{2}{*}{ LP 5} & $\begin{array}{l}\text { Using e-learning is } \\
\text { helpful in my studies } \\
\text { because I can receive } \\
\text { announcements from my } \\
\text { lecturers, supervisor and } \\
\text { faculty. }\end{array}$ & & IU 5 & $\begin{array}{l}\text { I intend to fully } \\
\text { integrate our work with } \\
\text { e- learning. }\end{array}$ \\
\hline & & & IU 6 & $\begin{array}{l}\text { I intend to recommend } \\
\text { the use of e- learning to } \\
\text { learning }\end{array}$ \\
\hline LS 1 & \multicolumn{4}{|c|}{$\begin{array}{l}\text { I agree that the personalised services provided by the e-learning } \\
\text { system satisfy my requirements. }\end{array}$} \\
\hline LS 2 & \multicolumn{4}{|c|}{ I am satisfied with the quality of the e-learning system. } \\
\hline LS 3 & \multicolumn{4}{|c|}{$\begin{array}{l}\text { I am satisfied with the difficulty level of e-learning content, activities } \\
\text { and tests. }\end{array}$} \\
\hline LS 4 & \multicolumn{4}{|c|}{ I am satisfied with the recommended adaptive e-learning path. } \\
\hline
\end{tabular}

\section{RESUlts AND DisCUSSION}

The basic sample demographic was the base on which distribution of respondent was conducted and the data obtained on the respondents' backgrounds came from the questionnaire. First, $46.9 \%$ of the respondents forming 106 of the total number of the participants were males while the rest forming $53.1 \%$ were females. Second, the participants were classified into four groups based on age: between 18-20, 21-24, 25-29 and 30 years old and above. These percentages of these respondents were $23.5 \%, 30.1 \%, 40.7 \%$ and $5.8 \%$ respectively. Regarding the participants level of study, $60.2 \%$ of them were undergraduates while $39.8 \%$ were postgraduates. As for their study programs, $38.1 \%$ of them were from social science programs, $21.2 \%$ were from science and technology 
programs. The main tool of analysis used to analyze the data obtained was the Structural Equation Modeling (SEM). The analysis was of two main phases: first, construct validity of the measurements, convergent validity of the measurements, discriminant validity of the measures was conducted. Second, the structural model was analyzed. This approach was used based on the recommendations of Hair et al. [29].

\section{A. Construct Validity of the Measurements}

The ability of the items generated to assess and measure a particular concept is known as the Construct validity [29]. In order to make sure that this is the case, the loadings of these items should by higher on the constructs they are supposed to measure than on the other constructs. The items generate throughout the related literature have undergone this process. The items were categorized under the different constructs based on the results of factor analysis. Table 1 illustrates the loading of these items and shows that their loadings are the highest on their related constructs [30]. Table 2 also shows the significant loadings of these constructs on their constructs.

Table2: Loading and cross-loadings of the items

\begin{tabular}{|c|c|c|c|c|c|c|c|}
\hline $\mathrm{N}$ & $\mathrm{F}$ & Code & IU & LP & LS & PEU & PU \\
\hline 1 & \multirow{6}{*}{ 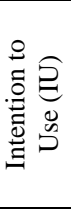 } & IU 1 & 0.832 & 0.607 & 0.595 & 0.571 & 0.552 \\
\hline 2 & & IU 2 & 0.861 & 0.649 & 0.669 & 0.599 & 0.577 \\
\hline 3 & & IU 3 & 0.847 & 0.655 & 0.666 & 0.585 & 0.580 \\
\hline 4 & & IU 4 & 0.832 & 0.633 & 0.632 & 0.543 & 0.539 \\
\hline 5 & & IU 5 & 0.806 & 0.564 & 0.622 & 0.555 & 0.525 \\
\hline 6 & & IU 6 & 0.757 & 0.587 & 0.570 & 0.511 & 0.478 \\
\hline 7 & \multirow{5}{*}{ 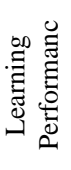 } & LP 1 & 0.598 & 0.789 & 0.719 & 0.534 & 0.580 \\
\hline 8 & & LP 2 & 0.576 & $\mathbf{0 . 8 3 0}$ & 0.677 & 0.552 & 0.549 \\
\hline 9 & & LP 3 & 0.602 & 0.787 & 0.560 & 0.562 & 0.569 \\
\hline 10 & & LP 4 & 0.578 & 0.779 & 0.503 & 0.513 & 0.531 \\
\hline 11 & & LP 5 & 0.587 & 0.735 & 0.488 & 0.498 & 0.474 \\
\hline 12 & \multirow{5}{*}{ 号. } & LS 1 & 0.706 & 0.693 & 0.833 & 0.555 & 0.575 \\
\hline 13 & & LS 2 & 0.624 & 0.619 & 0.823 & 0.517 & 0.546 \\
\hline 14 & & LS 3 & 0.669 & 0.621 & 0.869 & 0.548 & 0.560 \\
\hline 15 & & LS 4 & 0.617 & 0.627 & 0.829 & 0.528 & 0.537 \\
\hline 16 & & LS 5 & 0.552 & 0.607 & 0.826 & 0.481 & 0.511 \\
\hline 17 & \multirow{6}{*}{ 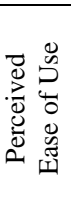 } & PEU 1 & 0.526 & 0.523 & 0.433 & 0.788 & 0.694 \\
\hline 18 & & PEU 2 & 0.486 & 0.538 & 0.506 & 0.802 & 0.607 \\
\hline 19 & & PEU 3 & 0.560 & 0.534 & 0.460 & 0.830 & 0.671 \\
\hline 20 & & PEU 4 & 0.519 & 0.434 & 0.496 & 0.774 & 0.432 \\
\hline 21 & & PEU 5 & 0.508 & 0.518 & 0.510 & 0.710 & 0.513 \\
\hline 22 & & PEU 6 & 0.553 & 0.578 & 0.528 & $\begin{array}{l}0.801 \\
\end{array}$ & 0.586 \\
\hline 23 & \multirow{6}{*}{ 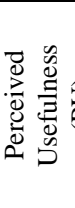 } & PU 1 & 0.584 & 0.608 & 0.538 & 0.650 & 0.805 \\
\hline 24 & & PU 2 & 0.571 & 0.555 & 0.549 & 0.655 & 0.835 \\
\hline 25 & & PU 3 & 0.504 & 0.566 & 0.525 & 0.591 & 0.828 \\
\hline 26 & & PU 4 & 0.510 & 0.553 & 0.553 & 0.567 & 0.800 \\
\hline 27 & & PU 5 & 0.549 & 0.546 & 0.521 & 0.649 & 0.839 \\
\hline 28 & & PU 6 & 0.491 & 0.535 & 0.509 & 0.622 & 0.772 \\
\hline
\end{tabular}

\section{B. Convergent Validity of the Measurements}

The values of composite reliability are shown in Table 2 . It can be clearly observed that they are above the recommended value of 0.7 as they are ranging between 0.888 to 0.926 . The same goes to the values of Cronbach's Alpha that are above 0.7. As illustrated in the table, these values range between 0.844 to 0.905 . As for the values of average variance extracted (AVE), they also exceed the value of 0.5 as they range between 0.592 to 0.699 indicating that the results are satisfactory. Looking at previous studies, it can be noticed that these results are higher than the ones of the previous research [29, 31]. Table 3 further illustrates the results of CFA of the measurement model.
Table 3: Convergent Validity

\begin{tabular}{|c|c|c|c|c|c|c|c|}
\hline $\mathrm{N}$ & $\mathrm{F}$ & Code & F.L & $\mathrm{CR}$ & AVE & $\mathrm{CA}$ & R Square \\
\hline 1 & \multirow{6}{*}{ 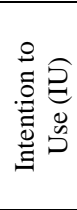 } & IU 1 & 0.832 & \multirow{6}{*}{0.926} & \multirow{6}{*}{0.678} & \multirow{6}{*}{$\begin{array}{l}0.90 \\
5\end{array}$} & \multirow{6}{*}{0.511} \\
\hline 2 & & IU 2 & 0.861 & & & & \\
\hline 3 & & IU 3 & 0.847 & & & & \\
\hline 4 & & IU 4 & 0.832 & & & & \\
\hline 5 & & IU 5 & 0.806 & & & & \\
\hline 6 & & IU 6 & 0.757 & & & & \\
\hline 7 & \multirow{5}{*}{ 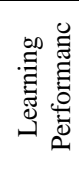 } & LP 1 & 0.789 & \multirow{5}{*}{0.888} & \multirow{5}{*}{0.616} & \multirow{5}{*}{$\begin{array}{l}0.84 \\
4\end{array}$} & \multirow{5}{*}{0.562} \\
\hline 8 & & LP 2 & 0.830 & & & & \\
\hline 9 & & LP 3 & 0.787 & & & & \\
\hline 10 & & LP 4 & 0.779 & & & & \\
\hline 11 & & LP 5 & 0.735 & & & & \\
\hline 12 & \multirow{5}{*}{ 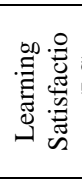 } & LS 1 & 0.833 & \multirow{5}{*}{0.921} & \multirow{5}{*}{0.699} & \multirow{5}{*}{$\begin{array}{l}0.89 \\
3\end{array}$} & \multirow{5}{*}{0.663} \\
\hline 13 & & LS 2 & 0.823 & & & & \\
\hline 14 & & LS 3 & 0.869 & & & & \\
\hline 15 & & LS 4 & 0.829 & & & & \\
\hline 16 & & LS 5 & 0.826 & & & & \\
\hline 17 & \multirow{6}{*}{ 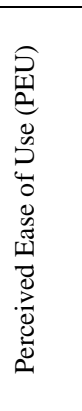 } & $\begin{array}{l}\text { PEU } \\
1\end{array}$ & 0.788 & \multirow{6}{*}{0.897} & \multirow{6}{*}{0.592} & \multirow{6}{*}{$\begin{array}{l}0.86 \\
1\end{array}$} & \multirow{6}{*}{0.000} \\
\hline 18 & & $\begin{array}{l}\text { PEU } \\
2\end{array}$ & 0.802 & & & & \\
\hline 19 & & $\begin{array}{l}\text { PEU } \\
3 \\
\end{array}$ & 0.830 & & & & \\
\hline 20 & & $\begin{array}{l}\text { PEU } \\
4\end{array}$ & 0.774 & & & & \\
\hline 21 & & $\begin{array}{l}\text { PEU } \\
5\end{array}$ & 0.710 & & & & \\
\hline 22 & & $\begin{array}{l}\text { PEU } \\
6\end{array}$ & 0.801 & & & & \\
\hline 23 & \multirow{6}{*}{ 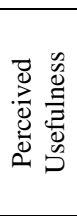 } & PU 1 & 0.805 & \multirow{6}{*}{0.922} & \multirow{6}{*}{0.662} & \multirow{6}{*}{$\begin{array}{l}0.89 \\
8\end{array}$} & \multirow{6}{*}{0.589} \\
\hline 24 & & PU 2 & 0.835 & & & & \\
\hline 25 & & PU 3 & 0.828 & & & & \\
\hline 26 & & PU 4 & 0.800 & & & & \\
\hline 27 & & PU 5 & 0.839 & & & & \\
\hline 28 & & PU 6 & 0.772 & & & & \\
\hline
\end{tabular}

\section{Discriminant Validity of the Measures}

The difference between a certain concept and its indicators on one side and another concept with its related indicators from another side is measured by the discriminant validity [32]. The value of AVE is found significant at $p=0.001$ exceeding 0.5. This indicates that the discriminant validity of all constructs is satisfactory [31]. The square root of the average variance shared by the items within a construct should be higher than the correlations between items in any two constructs Hair et al. [29]. Table 4 illustrates the discriminant validity of the constructs.

Table 4: Discriminant Validity

\begin{tabular}{|l|c|c|c|c|c|}
\hline \multicolumn{1}{|c|}{ Variables } & IU & LP & LS & PEU & PU \\
\hline Intention to Use & 0.925 & & & & \\
\hline Learning Performance & 0.637 & 0.891 & & & \\
\hline Learning Satisfactions & 0.562 & 0.524 & 0.944 & & \\
\hline Perceived Ease of Use & 0.534 & 0.487 & 0.567 & 0.976 & \\
\hline Perceived Usefulness & 0.611 & 0.637 & 0.458 & 0.579 & 0.892 \\
\hline
\end{tabular}

\section{Analysis of the Structural Model}

As the results on the measurement model came satisfactory, the current study is taking a step forward and starts testing the hypothesis by looking at the relations between the different constructs. The PLS algorithm under SmartPLS 3.0 was used to test the various hypothesis in this study. Tables 2, 3 and 5 illustrate the path coefficients generated. 


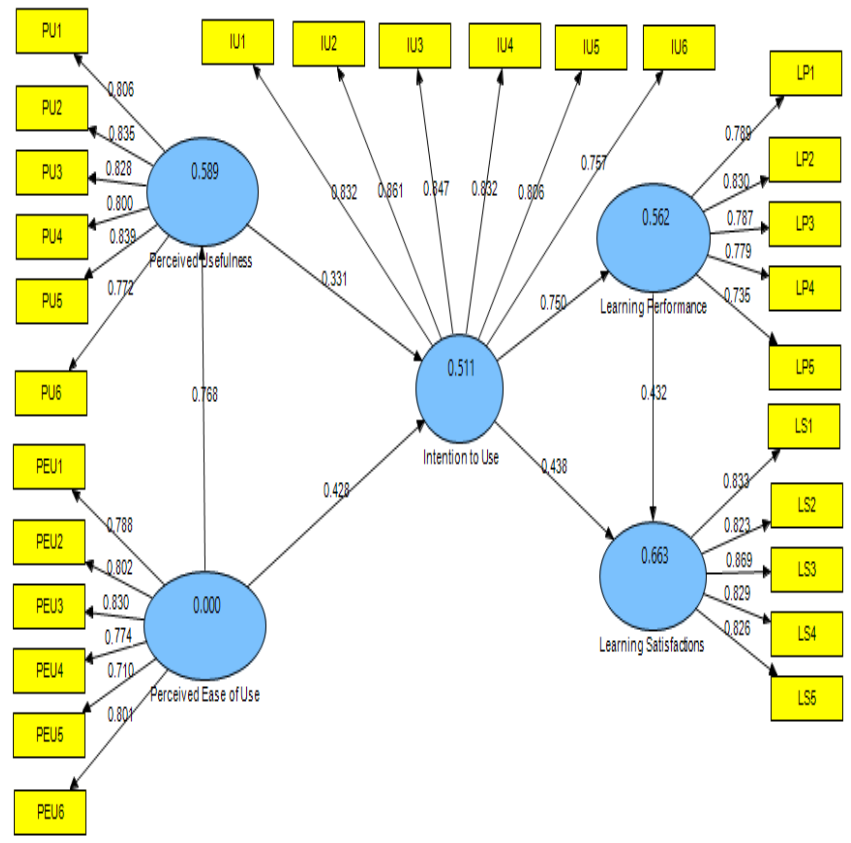

Figure 2: Path coefficient results

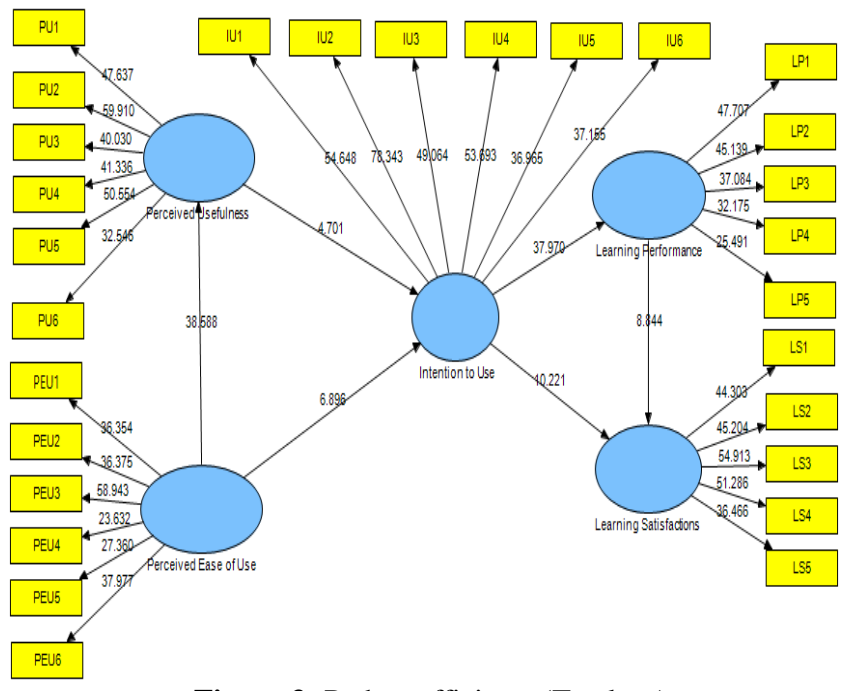

Figure 3: Path coefficients ( $T$ values)

Table 5: Hypotheses testing

The former indicates that there is a positive relation between intention to use e-learning and learning satisfactions while the latter indicates that intention to use e-learning and learning satisfactions found to have a positive relationship. The sixth hypothesis was also proved to be satisfactory as $(\beta=0.432$, $\mathrm{t}=8.844, \mathrm{p}<0.001$ ) indicating a positive relationship between learning performance and learning satisfactions. This study is an attempt to explore the relationships among perceived ease of use, perceived usefulness and intention to use e-learning in the context of tertiary education and their impact on the students' learning performance and learning satisfaction. The relation between these factors has been proven to be positive throughout the related literature [7, 10, 33]. In addition to the importance of these tools to the students in accomplishing their various academic tasks, these tools are also used to assess their academic performance. The use of these tools and application is encouraged and recommended by previous related studies including those done on the use of social media, online courses and e-learning in the context of tertiary education [12, 34, 35]. Differentiating characteristics are illustrated in this study concerning the student performance based on whether they are repeat or new students during the year the online learning platform was introduced. This means that the performance of both new and repeat students during the year of introducing online learning was consistent with that in previous years without the online learning platform. However, in terms of formative assessments it is evident that the introduction of online learning could have had positive impact on performance. This does not comply with Bhuasiri et al.'s [36] assertion that underprepared students fail to use e-learning platforms. The intention of using e-learning can be strongly predicted by perceived usefulness. The ease of use if found to be a major predictor of the students' intention to use e-learning $[6,7,10]$. The delivery of this context is considered an important aspect to look at as it need to be updated [12]. Users of e-learning are reported to be more likely to have access to the huge store of blended learning courses, and this is normally in line with the content of their field of study [37]. Three empirical pieces of evidence are illustrated in this study. One of those evidences is related to the adaptive e-learning among university students. Second

\begin{tabular}{|c|c|c|c|c|c|c|}
\hline $\mathrm{H}$ & Ind & Relation & Dep & Path & T values & Resultempirical evidence an applying Technology Acceptance \\
\hline 1 & $\mathrm{PU}$ & $\rightarrow$ & IU & 0.331 & 4.701 & Suppdrtodel (TAM) that in turn, affect intention to use e-learning. \\
\hline 2 & PEU & & IU & 0.428 & 6.896 & Suppdrted third empirical evidence is related to substantial \\
\hline 3 & PEU & $\rightarrow$ & $\mathrm{PU}$ & 0.768 & 38.588 & Supp甲litedretical contribution to previous knowledge an adaptive \\
\hline 4 & IU & $\rightarrow$ & LP & 0.750 & 37.970 & Suppertedarning among university students with Technology \\
\hline 5 & IU & $\rightarrow$ & LS & 0.438 & 10.221 & Supportedeptance Model (TAM) in the educational context [38, 39, \\
\hline 6 & LP & $\rightarrow$ & LS & 0.432 & 8.844 & Suppgriged \\
\hline
\end{tabular}

The six hypotheses proposed in the current study were supported. In details, a positive relation between perceived usefulness and intention to use e-learning was found as $(\beta=0.331, \mathrm{t}=4.701, \mathrm{p}<0.001)$. This clearly indicates that hypothesis 1 in this study is supported. Moreover, the perceived ease of use was found to have a positive as well as a significant relationship with the intention to use e-learning $(\beta=0.428, \quad \mathrm{t}=6.896, \quad \mathrm{p}<0.001) \quad$ supporting the second hypothesis. The same goes for the relation between perceived ease of use and perceived usefulness which resulted as $(\beta=0.768, t=38.588, p<0.001)$ providing support for the third hypothesis. As for hypotheses 4 and 5 , the results came as $(\beta=0.750, \mathrm{t}=37.970, \mathrm{p}<0.001)$ and $(\beta=0.438, \mathrm{t}=10.221$, $\mathrm{p}<0.001)$ indicating the significance of these two hypotheses.

\section{CONCLUSION AND FUTURE WORK}

The aim of the current study was to investigate students' satisfaction of e-learning. All of the six hypotheses proposed in this study were supported. These constructs: learning performance, learning satisfaction, perceived ease of use, perceived usefulness and intention to use e-learning among university students were proven to have significant relationships with one another. It is observed through the date obtained that students are able to share knowledge and interact with their counterparts through E-learning. Based on the results, the current study recommends future research to take into consideration other 
aspects related to e-learning environments. The issue individual's intention is also recommended to be taken into consideration by future research looking at how it is influenced by student characteristics and the quality of services. Moreover, other aspects should be investigated such as the support for e-learning and its relationship to self-efficacy; interactivity and collaborative learning and the impact of e-learning on students' performance and engagement. Finally, the sample under investigation should be increased to provide better insights.

\section{ACKNOWLEDGMENT}

We would like to thank the Research Management Centre (RMC) at Universiti Teknologi Malaysia (UTM) for funding this project under grant number PY/2019/00809.

\section{REFERENCES}

1. H.R. Amado-Salvatierra, J. R. Hilera, S. O. Tortosa, R. H. Rizzardini and N. Piedra, Towards a Semantic Definition of a Framework to Implement Accessible e-Learning Projects. Journal of Universal Computer Science, 22(7) 2016, pp 921 - 942

2. K.H. Fee, Delivering E-Learning: A Complete Strategy for Design Application and Assessment, 2005, London and Philadelphea: Kogan Page.

3. K. Cheng, A Research Study on Students' Level of Acceptance in Applying E-Learning for Business Courses - A Case Study on a Technical College in Taiwan. Journal of American Academy of Business. 2006, Volume 8. Number 2. pp: 265-270.

4. T. FitzPatrick, "Key Success Factors of eLearning in Education: A Professional Development Model to Evaluate and Support eLearning", US-China Education Review, 2012, A 9 , 2012, 789-795

5. H Li, J. Masters, "ELearning and knowledge management in the early years: Where are we and where should we go", Knowledge Management and eLearning: An International Journal, 2009, 1(4), 245-250.

6. W. M. Al-rahmi, M. S. Othman and L. M. Yusuf, The Effectiveness of Using E-Learning in Malaysian Higher Education: A Case Study Universiti Teknologi Malaysia. Mediterranean Journal of Social Sciences, 6(5): 2015, pp625- 637.

7. W. M. Al-rahmi, M. S. Othman and L. M. Yusuf, Exploring the Factors that Affect Student Satisfaction through Using E-Learning in Malaysian Higher Education Institutions. Mediterranean Journal of Social Sciences, 6(4): 2015, pp299- 310.

8. C. M. Finneran and P. Zhang, A person-artefact-task (PAT) model of flow antecedents in computer-mediated environments. International Journal of Human Computer Studies. 59(4):2008, pp475-496.

9. Y. Wang, Assessment of learner satisfaction with asynchronous electronic learning systems. Information and Management. 41:2003, pp75-86.

10. W. M. Al-Rahmi, A. Norma, O. Mohd Shahizan, I. A. Ahmed, A. Osama, A. S. Ali, and A. R. Nur Shamsiah. "Use of E-Learning by University Students in Malaysian Higher Educational Institutions: A Case in Universiti Teknologi Malaysia." IEEE Access 6 (2018): $14268-14276$.

11. A. E. Mohamed, A. Hanafi and H. Afendi, Summary of Findings on the Status, Trends and Challenges of e-Learning Implementation. In Mohamed Amin Embi (Eds.), e-Learning in Malaysian Higher Education Institutions. 2011, pp107-115.

12. W. M. Al-Rahmi and A. M. Zeki, A Model of Using Social Media for Collaborative Learning to enhance learners' Performance on learning. Journal of King Saud University - Computer and Information Sciences, http://dx.doi.org/10.1016/j.jksuci.2016.09.002. 2017. pp 1- 23.

13. H. Wixom, \& A. Todd, "A theoretical integration of user satisfaction and technology acceptance", Information Systems Research, 16(1), 2005, 85-102.

14. V. Venkatesh, G, Morris, B. Davis, \& D. Davis, D. (2003). User acceptance of information technology: Toward a unified view. MIS Quarterly, 27(3), 425-478.

15. F.D Davis, "Perceived usefulness, perceived ease of use and user acceptance of information technology. MIS Quarterly 13, 1989, 319-340.
16. E. M. Rogers, "Diffusion of Innovations: modifications of a model for telecommunications", In Die Diffusion von Innovationen in der Telekommunikation 1995, (pp. 25-38). Springer, Berlin, Heidelberg.

17. L. Tornatzky, L. and K. Klein. "Innovation Characteristics and Innovation Adoption-Implementation: A Meta-Analysis of Findings", IEEE Transactions on Engineering Management, 29(1), 1982, pp. 28-45.

18. P. Legris, J. Ingham, \& P. Collerette, P. "Why do people use information technology? A critical review of the technology acceptance model", Information \& management, 40(3), 2003, 191-204.

19. A. Tajudeen Shittu, K. Madarsha Basha, N. Suryani Nik, \& T. Badariah Tunku Ahmad, "Investigating students' attitude and intention to use social software in higher institution of learning in Malaysia. Multicultural Education \& Technology Journal, 5(3), 2011, 194-208.

20. P. Esmaeilzadeh, M. Sambasivan, N. Kumar, \& H. Nezakati, "The effect of knowledge sharing on technology acceptance among physicians". J. Bus. Admin. Manage. Sci. Res, 2(5), 2013, 123-132.

21. K.-C. Chen, \& S. J. Jang, "Motivation in online learning: Testing a model of self-determination theory", Computers in Human Behavior, 26(4), 2010, 741- 752.

22. N. Mallat, M. Rossi, V.K. Tuunainen, \& A. Oorni, "The impact of use situation and mobility on the acceptance of mobile ticketing services", In System Sciences, 2006. HICSS'06. Proceedings of the 39th Annual Hawaii International Conference on (Vol. 2, pp. 42b-42b). 2006, IEEE.

23. J. H. Wu, \& S.C. Wang, "What drives mobile commerce?: An empirical evaluation of the revised technology acceptance model", Information \& management, 42(5), 2005, 719-729.

24. T. Traphagan, J. V. Kucsera, \& K. Kishi, "Impact of class lecture webcasting on attendance and learning", Educational Technology Research and Development, 58(1), 2010, 19-37.

25. S.S. Liaw, Understanding computers and the Internet as a work assisted tool. Computers in Human Behavior. 23(1): 2007, pp399-414.

26. A. Razak, Improvement in ELearning in term of communication. Thesis Master IT. Universiti Teknologi Malaysia, Library, 2010, pp 1- 198.

27. Q. Yahya, Strategies for enhancing E-Learning implementation in Universiti Teknologi Malaysia UTM. Thesis Master IT. Universiti Teknologi Malaysia, Library, 2010, pp 1- 131.

28. M. Yarandi, H. Jahankhani, \& A. R. Tawil, "A personalized adaptive e-learning approach based on semantic web technology", webology, 10(2), 2013, Art-110.

29. J.F. Hair, C. M. Ringle and M. Sarstedt, PLS-SEM: Indeed a silver bullet. Journal of Marketing Theory and Practice. 18(2): 2010, pp139-152.

30. M. Chow, D. K. Herold, T. M. Choo and K. Chan, Extending the technology acceptance model to explore the intention to use Second Life for enhancing healthcare education. Computers and Education. 59(4): 2012, pp1136-1144

31. C. Fornell and D. F. Larcker, Evaluating structural equation models with unobservable variables and measurement error. Journal of Marketing Research, 1981, pp39-50.

32. R. P. Bagozzi, F. D. Davis and P. R. Warshaw, Extrinsic and intrinsic motivation to use computers in the workplace. Journal of Applied Social Psychology, 22(14): 1992, pp111-1132.

33. J. Leem and B. Lim, The current status of e-learning and strategies to enhance educational competitiveness in Korean higher education. The International Review of Research in Open and Distance Learning. 8(1) 2007

34. W. M. Al-Rahmi, M. S. Othman and L. M. Yusuf LM, The role of social media for collaborative learning to improve academic performance of students and researchers in Malaysian higher education. The International Review of Research in Open and Distributed Learning, 16(4).2015, pp 1- 18.

35. S. Sanchez-Gordon and S. Lujan-Mora, How Could MOOCs Become Accessible? The Case of edX and the Future of Inclusive Online Learning. Journal of Universal Computer Science, 2016, pp55-81.

36. W. Bhuasiri, O. Xaymoungkhoun, H. Zo, J.J. Rho, \& A. P. Ciganek, "Critical success factors for e-learning in developing countries: A comparative analysis between ICT experts and faculty", Computers \& Education, 58(2), 2012, 843-855.

37. T. Mayisela, The potential use of mobile technology: enhancing accessibility and communication in a blended learning course. South African Journal of Education, 33(1), 2013, pp1- 18.

38. W. M. Al-Rahmi, N. Yahaya, M.M. Alamri, N.A. Aljarboa, Y.B Kamin, and F.A. Moafa. "A Model of Factors Affecting Cyber Bullying Behaviors among University Students. IEEE Access, 7, 2978-2985 2018. 
39. W. M. Al-Rahmi, N. Yahaya, M.M. Alamri, N.A. Aljarboa, Y.B. Kamin, and M.S.B. Saud. "How Cyber Stalking and Cyber Bullying Affect Students' Open Learning". IEEE Access, 7, 20199-20210. 2019.

40. W. M. Al-Rahmi, N. Yahaya, A.A. Aldraiweesh, M.M. Alamri, N.A. Aljarboa, U. Alturki, and A.A. Aljeraiwi. "Integrating Technology Acceptance Model with Innovation Diffusion Theory: An Empirical Investigation on students' Intention to use E-Learning Systems”. IEEE Access, 7, 26797-26809, 2019.

41. W. M. Al-Rahmi, N. Yahaya, A.A. Aldraiweesh, U. Alturki, M.M. Alamri, M.S. Saud, Y.B. Kamin, A.A. Aljeraiwi, and A.O. Alhamed. Big Data Adoption and Knowledge Management Sharing: An Empirical Investigation on Their Adoption and Sustainability as a Purpose of Education. IEEE Access, 7, 47245-47258, 2019. 